\title{
Valparaiso: la vieja y nueva bohemia
}

\author{
Valparaiso: new and old \\ bohemia
}
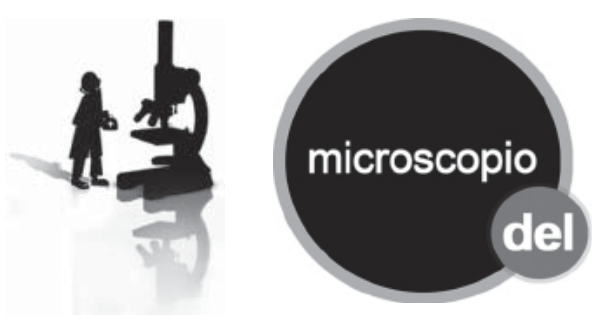

\section{y la cultura}

$\mathrm{E}$ 1 puerto de Valparaíso es indefinible e inagotable. Declarado patrimonio de la humanidad por la UNESCO en el año 2003, ha transitado de la gloria al abandono y del abandono a la gloria una y otra vez.

El cineasta Aldo Francia retrató en un filme de 1969 los contrastes de la ciudad: "Valparaíso mi amor" es la historia de una familia que habita en la pobreza del cerro Cordillera, lejos del esplendor de principios de siglo y de la bohemia y los cabarets del barrio del puerto, que se extiende a sus pies.

Desde el siglo diecinueve, y a pesar de las sucesivas crisis, los terremotos, las migraciones, y la construcción del canal de Panamá, el puerto bullía de actividad, y marinos y marineros de distintas nacionalidades podían pasar hasta semanas en tierra; los trabajadores portuarios eran numerosos ya que las faenas se hacían a fuerza de trabajo manual. El estibador en el barco sacando cargas, el movilizador recibiéndolas en el muelle, el embalador en las bodegas fiscales y el marino en la bahía.

El barrio del puerto, alrededor del la Plaza Echaurren, es el más antiguo de la ciudad; se extiende por algunas pocas manzanas, entre la
Plaza de la Aduana, y la Plaza Sotomayor. Este barrio era el paradero y refugio de marineros, trabajadores portuarios, prostitutas y muchos otros personajes, como el "choro del puerto", compadrito o malandra temido y respetado.

Otros asiduos eran los contrabandistas, y los hombres de alta sociedad, clientes de los prostíbulos caros de la calle Márquez y Clave, donde llegaban en lujosos automóviles. Famosos fueron "Los siete espejos”, "La casa amarilla” y “El violeto” llamado así por el apodo de su dueño que solía sentarse al piano todas las noches.

Los cabarets y bares más renombrados de la época eran el American Bar, ubicado frente a la Plaza de la Aduana, el Roland Bar, y el Flamingo Rose en la calle Cochrane, que aún subsiste. Por las noches, las bandas de los buques extranjeros se transformaban en orquestas de baile, y las muchachas que atendían tenían una libreta donde anotaban las frases más útiles para comunicarse con ellos, en innumerables idiomas.

Con la mecanización del puerto y el toque de queda, llega el fin de esta antigua bohemia. La faena portuaria ahora es barco, grúa, con- tenedor y camión y los marineros sólo bajan ocasionalmente a tierra. En las décadas de 1980 y 1990 el barrio entra en una de sus etapas de mayor pobreza y abandono, al igual que el resto de la ciudad.

Hoy Valparaíso y el barrio del puerto viven un lento y difícil resurgimiento, de la mano del rescate de su patrimonio y del empuje motivado por su condición de patrimonio de la humanidad.

Una nueva bohemia ha venido en reemplazo de la que murió. Por las calles Blanco, Cochrane y Errázuriz se restauran edificios, se abren nuevos cafés, bares, pubs y restaurantes, junto con salas de arte, de música popular y de jazz. Aún es un barrio bravo, donde entran los valientes, pero también es centro de reunión de artistas, escritores, poetas y músicos.

Probablemente, y siguiendo el consejo de Serrat, "un viejo ex cliente, pura sensatez, hace bloques de pisos amueblados, en un tono rosa... pero aquello era otra cosa".

\section{Referencias}

1.- http://ciudaddevalparaiso.cl (con acceso el 24 de abril de 2011).

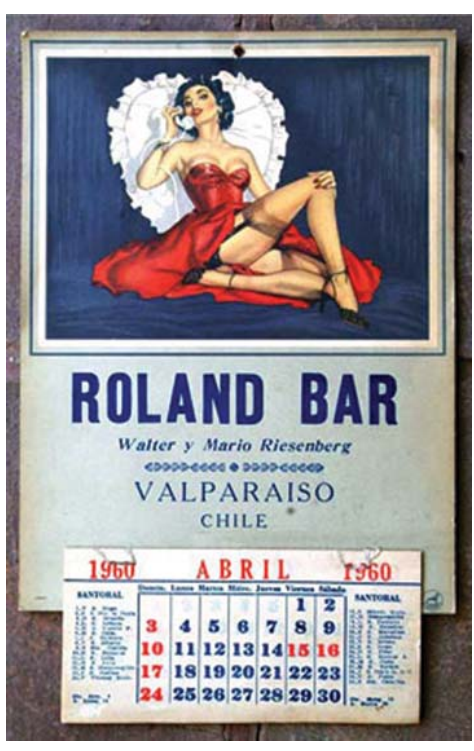

Figura 1. Calendario del Roland bar de 1960. ciudaddevalparaiso.cl

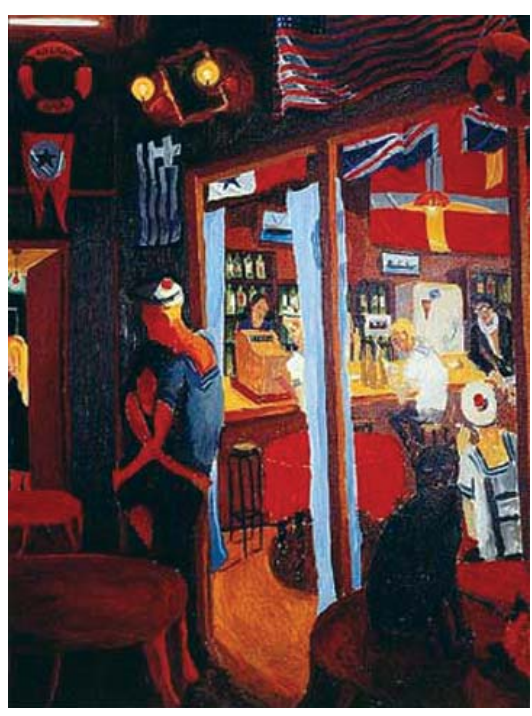

Figura 2. "Marinos del Jean Darc en el Roland Bar" óleo de Gonzálo Ilabaca, calendario colección Philips 1994 historia de la pintura chilena.
Ernesto Payá G. Hospital de Carabineros, Santiago

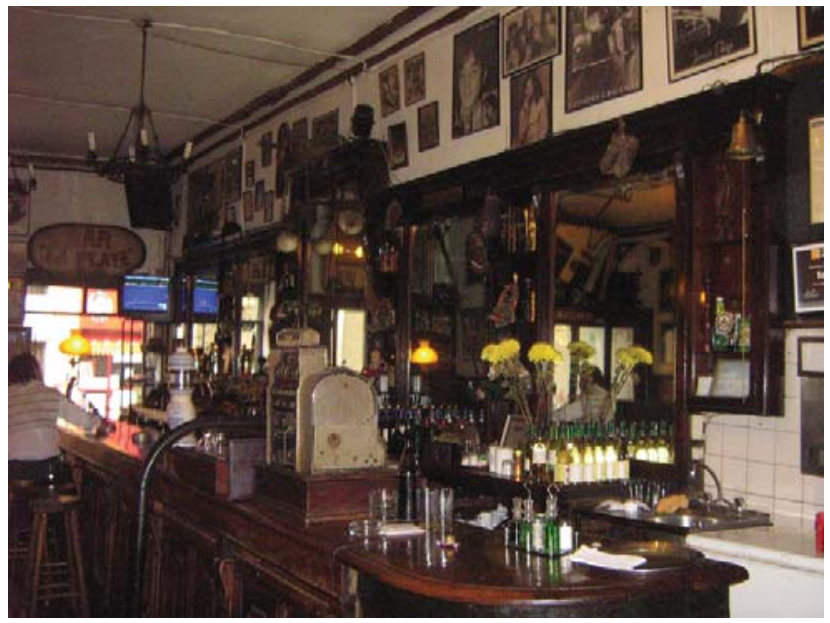

Figura 3. El bar "La playa" de la calle Cochrane en la actualidad. Fotografía: E. Payá 